\title{
Defined Substance Administration Dose
}

National Cancer Institute

\section{Source}

National Cancer Institute. Defined Substance Administration Dose. NCI Thesaurus. Code C93796.

The quantity of a substance or medication to be administered. 